\title{
Distribution and illegal killing of the Endangered Indian pangolin Manis crassicaudata on the Potohar Plateau, Pakistan
}

\author{
Tarig Mahmood, Faraz Akrim, Nausheen Irshad, Riaz Hussain, Hira Fatima \\ Shaista Andeeb and Ayesha Ainetasham
}

\begin{abstract}
The Endangered Indian pangolin Manis crassicaudata, a burrowing, armoured mammal, plays an important role in the food web by consuming insects and termites. In Pakistan the species' range includes the $22,000 \mathrm{~km}^{2}$ Potohar Plateau, where it is under pressure from illegal hunting for its scales and requires conservation attention. We used a geographical information system to quantify the range of the Indian pangolin on the Plateau and to compare this with the range estimated in the IUCN Red List assessment of the species. We found that the species occupies c. $89 \%$ of the Plateau, in eight of the 10 protected areas, compared with the IUCN estimate of $71 \%$, and we recorded the species at 40 locations on the Plateau outside the range predicted by the IUCN assessment. We collected data on the illegal capture and killing of the species, recording 412 individuals that had been killed at 48 locations between January 2011 and the end of April 2013. The highest number of killings was recorded in Chakwal District ( $\mathrm{n}=156$, at 13 sites) followed by the Attock District ( $n=149$, at eight sites). Although the Indian pangolin's range on the Potohar Plateau is c. $18 \%$ larger than that estimated in the IUCN assessment, the species is under pressure from illegal killing and requires urgent conservation measures to save the small remaining population and avoid the extirpation of this vital insectivorous predator from the area.
\end{abstract}

Keywords Distribution, Indian pangolin, IUCN assessment, killing, Manis crassicaudata, Pakistan, Potohar, spatial range

Supplementary material for this article can be found at https://doi.org/10.1017/So030605317000023

\footnotetext{
Tariq Mahmood (Corresponding author), Faraz Akrim, Nausheen Irshad, Riaz Hussain, Hira Fatima and Shaista Andleeb Department of Wildlife Management, Pir Mehr Ali Shah Arid Agriculture University, Rawalpindi 46300, Pakistan. E-mail tariqjanjua75@uaar.edu.pk

Ayesha Ainetasham Zoology Department, University of the Punjab, Lahore, Pakistan

Received 14 October 2016. Revision requested 2 December 2016.

Accepted 4 January 2017. First published online 16 May 2017.
}

\section{Introduction}

The Indian pangolin Manis crassicaudata is categorized 1 as Endangered on the IUCN Red List (Baillie et al., 2014) because of its declining populations, which is a result of illegal hunting and increased levels of poaching for its scales and meat (Baillie et al., 2014). It is one of four Asian pangolin species, all of which have protective keratinized scales (Gaudin et al., 2006; Gaubert, 2011). The scales are used in traditional medicine in China and other countries, and Indian pangolins are traded illegally throughout East Asia (Challender et al., 2015), with many reports of seizures in Vietnam in recent years (EIA, 2015).

All eight species of pangolins (four Asian and four African) are on Appendix I of CITES (2017), and pangolins are considered to be the most trafficked wild mammal globally (Challender et al., 2015), with an estimated $>277,000$ individuals of both Asian and African origin traded since 200o. This trade is recognized as having a severe impact on the status of pangolin populations (Challender et al., 2015).

The Indian pangolin occurs in five countries: Pakistan, India, Nepal, Bangladesh and Sri Lanka (Baillie et al., 2014). In Pakistan the distribution is localized, with the species occurring in the provinces of Sind, Balochistan, some parts of Khyber Pakhtunkhawa and Punjab, including the Potohar Plateau (Roberts, 1997).

The Indian pangolin occurs in barren hilly areas and subtropical thorn forests (Roberts, 1997), usually ranging from moist to dry and thorn to grassland (Pai, 2008). It occurs at naturally low population densities and prefers forested environments of various types (Gaudin et al., 2006). It is also found in ruined wasteland near human settlements (Yang et al., 2007). The pangolin's scales provide defence against predators; when threatened, it rolls up into a ball to protect its delicate, vulnerable underside. Demand for the scales for use in traditional medicine has fuelled intensive poaching of the species, resulting in a decline of c. $79 \%$ in its native range (Irshad et al., 2015).

The Potohar Plateau is the core distribution range of the Indian pangolin in Pakistan, with only localized, patchy distributions in other areas. Previous studies (e.g. Mahmood et al., 2012) have highlighted the illegal trade and killing of Indian pangolins in Pakistan and the smuggling of their scales into China via Hong Kong (and perhaps 
Singapore). In April 2012 information was reported (GACC, 2012) on a seizure in China of $25.4 \mathrm{~kg}$ of pangolin scales that were apparently sourced from Pakistan, where illegal smuggling is facilitated by weak law enforcement.

We aimed to estimate the distribution range of the Indian pangolin on the Potohar Plateau, where a high intensity of illegal killing has been reported, and compare it with the IUCN estimate, to assess the intensity of illegal hunting pressure on the species on the Plateau, and to evaluate the efficacy of the protection system in place.

\section{Study area}

The study was conducted on the Potohar Plateau in northeast Pakistan (Fig. 1) during 2011-2013. The 22,255 $\mathrm{km}^{2}$ study area comprises four districts (Attock, 6,857 $\mathrm{km}^{2}$; Chakwal, 6,525 $\mathrm{km}^{2}$; Jhelum, 3,587 km² Rawalpindi, 5,286 $\mathrm{km}^{2}$ ), and also some parts of the capital city, Islamabad (Bhutta, 1999). The Plateau is at $330-1,000 \mathrm{~m}$ altitude and the climate is semiarid to humid, with mean annual rainfall of $380-510 \mathrm{~mm}$. The mean maximum temperature in summer is $45^{\circ} \mathrm{C}$, dropping to below freezing during winter (Encyclopaedia Britannica, 2010). Of the 178 protected areas in Pakistan 10 occur on the Potohar Plateau: six National Parks (Kala Chitta, Chinji, Ayub, Margalla Hills, Murree-Kahuta-Kotli Sattiyan and Ayubia), two Wildlife Sanctuaries (Chumbi Surla and Islamabad) and two Game Reserves (Domeli-Diljaba and Khairi Murat; Fig. 1).

\section{Methods}

Preliminary species occurrence data were obtained by interviewing local people using a questionnaire (Supplementary Material 1). Field data were collected during surveys of all natural areas of the four districts (Jhelum, Chakwal, Rawalpindi and Attock) of the Plateau. The interviews and field surveys were conducted between January 2011 and the end of April 2013. The field surveys were conducted using a motor vehicle driven at $25-30 \mathrm{~km}$ per hour along all accessible roads, guided by the published occurrence records of the species. Direct (sightings, capture, dead bodies) and indirect (burrows, faeces) signs of the species were recorded at stops every 5-7 km. Thorough searches were carried out at sites where the species was reported to occur. Geographical coordinates of the locations of occurrence were recorded using a global positioning system, and were used to construct distribution maps of the species and estimate its distribution range in the study area.

The occurrence data were georeferenced and uploaded to GoogleEarth (Google Inc., Mountain View, USA) and saved in Keyhole Markup Language format before being imported into QGIS v. 1.8.o (QGIS Development Team, 2012) and converted into shapefiles. The result was a layer of location

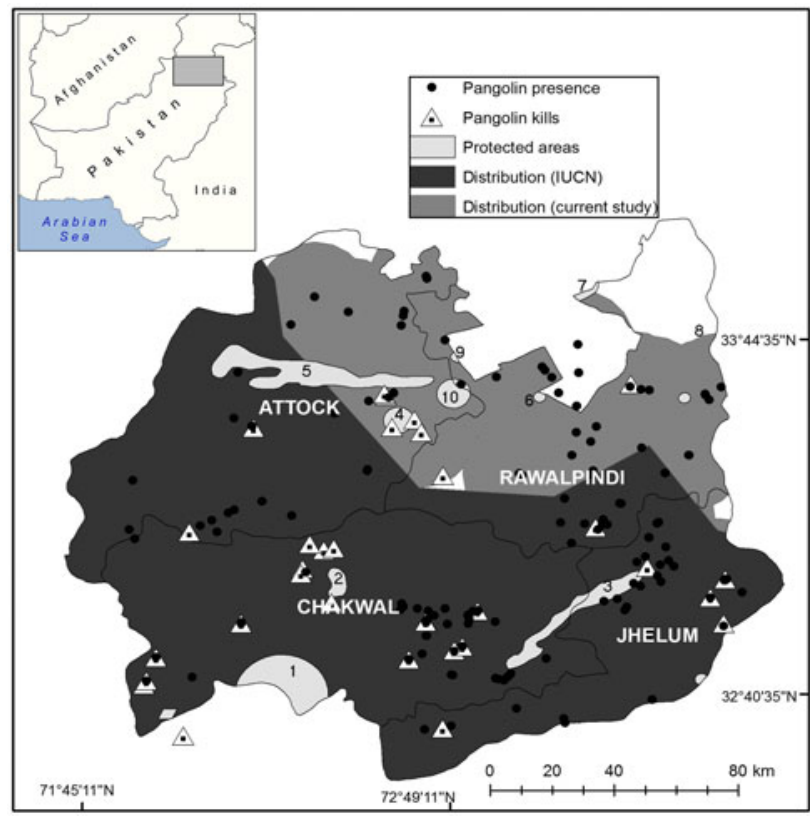

FIG. 1 The distribution of the Indian pangolin Manis crassicaudata on the Potohar Plateau estimated by this study and indicated by the IUCN assessment for the species (Baillie et al., 2014), with locations where pangolins were recorded, and locations where illegal capture and killing of pangolins was recorded. Protected areas are numbered as in Table 2.

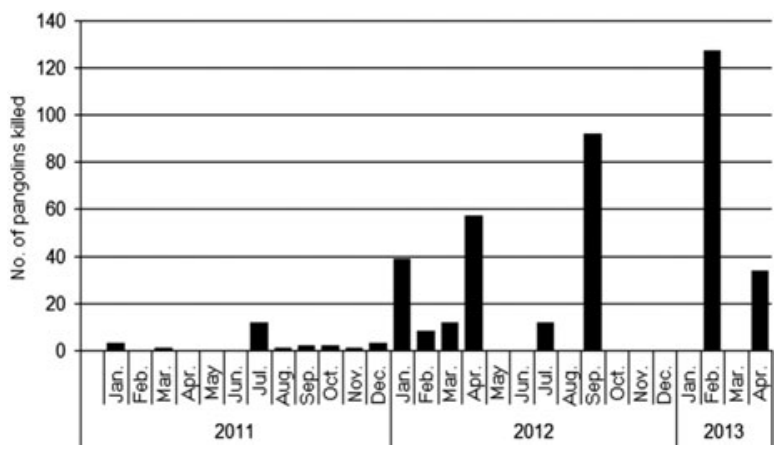

FIG. 2 Numbers of Indian pangolins killed illegally on Potohar Plateau, Pakistan (Fig. 1) during January 2011-April 2013.

points where the species was known to be present. For each location point we created a buffer of $5 \mathrm{~km}^{2}$, which approximates our estimate of the home range size of the Indian pangolin in Pakistan based on its daily activity. There are no published records of the home range size of the Indian pangolin, although the home range of the Sunda pangolin Manis javanica in Singapore was estimated to be considerably smaller (c. $0.7 \mathrm{~km}^{2}$ for females, and larger for males; Lim \& Ng, 2008).

We then clipped areas outside the study area, using a shapefile of the Plateau obtained from the global topographical data layer from WebGIS (2012). We created a polygon incorporating all the buffers to construct the distribution range of the Indian pangolin in the study area. The 
TABLE 1 Records of illegal capture and killing of the Indian pangolin Manis crassicaudata in the four districts of the Potohar Plateau (Fig. 1) during 2011-2013.

\begin{tabular}{|c|c|c|}
\hline Site name & $\begin{array}{l}\text { Date of record } \\
\text { collection }\end{array}$ & Details of capture/kill \\
\hline \multicolumn{3}{|l|}{ Jhelum District } \\
\hline Dhoke Jamroz & Undated & 1 jacket of scales \\
\hline PD Khan & Undated & 5 dead pangolins \\
\hline PD Khan & July 2011 & 2 captures, 10 kills \\
\hline Diljaba-Domeli & Aug. 2011 & 1 complete scale jacket \\
\hline Farash Pamal & Apr. 2012 & 1 individual killed \\
\hline PD Khan & Apr. 2012 & 2 live captures, 2 killed, 1 scale jacket (in addition to the kills) \\
\hline Mohal & 10 Apr. 2012 & 2 pangolins caught by nomads \\
\hline Rohtas & 10 Apr. 2012 & 12 pangolins reported to be caught \& sold to nomads \\
\hline Dhok Rajo & 10 Apr. 2012 & 9 pangolins caught \& sold by local people (nomads gave $15-20 \mathrm{~kg}$ fish for 1 pangolin) \\
\hline Dhongi, Sohawa & 10 Apr. 2012 & $\begin{array}{l}\text { 15-20 pangolins caught in } 2-3 \text { months; no more pangolins were found here. Nomads } \\
\text { distributed cards to local young people to collect information about pangolins, for } \\
\text { poaching purposes. }\end{array}$ \\
\hline \multicolumn{3}{|l|}{ Chakwal District } \\
\hline Jubairpur & Undated & 5 dead pangolins \\
\hline Kallar Kahar & Undated & 2 pangolins killed \\
\hline Mureed & Jan. 2011 & 1 adult male \\
\hline Chumbi Surla & Jan. 2011 & 1 adult male, plus $1 \mathrm{~kg}$ of scales \\
\hline Thoha Mehram & Sep. 2011 & 2 individuals \\
\hline Jubairpur & Oct. 2011 & 2 individuals \\
\hline Jubairpur & Dec. 2011 & 3 individuals \\
\hline Sardhi, Kallar Kahar & Feb. 2012 & 2 individuals \\
\hline Ratta Sharif, Kallar Kahar & Mar. 2012 & 2 individuals \\
\hline Talagang city & Jan. 2012 & 3 individuals \\
\hline Chakwal city & Feb. 2012 & $24 \mathrm{~kg}$ of scales \\
\hline Mathrala & 20 Feb. 2013 & $\begin{array}{l}5-6 \text { pangolins caught by local people, plus } 10-15 \text { caught in December } 2012 \text { by local } \\
\text { people \& sold to nomads }\end{array}$ \\
\hline Kot sarang & 20 Feb. 2013 & $10-20$ caught $\&$ sold for PKR 2,000-5,000 each \\
\hline Dhok lunda & 21 Feb. 2013 & 7 caught in previous few months \\
\hline Dhoke Sehla & 21 Feb. 2013 & 4 caught by local people \& sold to nomads \\
\hline Khokhar Zair & 21 Feb. 2013 & 4 caught by local people \& sold to nomads \\
\hline Mureed & 21 Feb. 2013 & 2 caught by local people, 1 more killed \\
\hline Talagang & 21 Feb. 2013 & $20-30$ caught in previous few months \\
\hline Lawa & 20 Feb. 2013 & 34 pangolins caught by nomads \\
\hline Chakora & 20 Feb. 2013 & 1 pangolin caught by local farmer \\
\hline Chandu wali & 20 Feb. 2013 & 3 caught in previous 3 months \\
\hline Danda Shah Balawal & 20 Feb. 2013 & 7 caught in previous few months, plus 1 killed \\
\hline \multicolumn{3}{|l|}{ Rawalpindi District } \\
\hline Ghakkar Sanhal & Undated & 5 killed \\
\hline Malpur -Islamabad & Undated & 1 adult, plus 2 baby pangolins, plus 1 road kill \\
\hline Kanyat Ladhu & Mar. 2011 & 1 individual \\
\hline Chakri village & Nov. 2011 & 1 individual \\
\hline Banni Gala & Feb. 2012 & 3 individuals \\
\hline Chakri & 27 Apr. 2013 & 7 pangolins caught, plus 2 caught in previous week \\
\hline Kanyat Ladhu & 27 Apr. 2013 & $\begin{array}{l}1 \text { killed; all pangolins present here were caught during previous } 8-10 \text { months and there } \\
\text { are none remaining }\end{array}$ \\
\hline Kanaisar & 28 Apr. 2013 & 16 caught in previous 3 months \\
\hline Attock District & & \\
\hline $\begin{array}{l}\text { Khairi Moorat, Near } \\
\text { Tanaza Dam }\end{array}$ & 13 Sep. 2012 & 50 caught (during Jan.-Sep. 2012) \\
\hline Tanaza Dam colony & 12 July 2012 & 2 caught by watchman \\
\hline Jaspal & 13 Sep. 2012 & 3 caught by local people \\
\hline Near Jamat Chowk & 12 Sep. 2012 & $25-30$ caught by nomads in 2 months \\
\hline Haddo wali & 14 Sep. 2012 & $\begin{array}{l}\text { 20-30 caught during previous } 3 \text { months. Population extirpated according to local } \\
\text { people }\end{array}$ \\
\hline
\end{tabular}


Table 1 (Cont.)

\begin{tabular}{lll}
\hline Site name & $\begin{array}{l}\text { Date of record } \\
\text { collection }\end{array}$ & Details of capture/kill \\
\hline Rattowal, Fateh Jang & 16 Sep. 2012 & 6-7 caught \\
Dhok Chaki & 16 Sep. 2012 & $7-8$ caught by local boys \& sold to nomads \\
Kisran & 16 Sep. 2012 & 14 caught by nomads in previous 3 months \\
\hline
\end{tabular}

TABLE 2 The 10 protected areas on the Potohar Plateau, Pakistan (Fig. 1), indicating whether the Indian pangolin has been recorded and whether there were any records of poaching or killing of the species during 2011-2013 (Table 1).

\begin{tabular}{|c|c|c|c|c|c|c|}
\hline & Protected area & Designation & District & $\begin{array}{l}\text { Area } \\
\left(\mathrm{km}^{2}\right)\end{array}$ & $\begin{array}{l}\text { Pangolin } \\
\text { occurrence }\end{array}$ & Poaching/killing \\
\hline 1 & Chumbi Surla & $\begin{array}{l}\text { Wildlife } \\
\text { Sanctuary }\end{array}$ & Chakwal & 559 & Yes & $\begin{array}{l}\text { Yes, } 1 \text { adult male captured plus } \\
1 \mathrm{~kg} \text { scales }\end{array}$ \\
\hline 2 & Chinji & National Park & Chakwal & 61 & Yes & No evidence \\
\hline 3 & Diljaba-Domeli & Game Reserve & Jhelum & 1,181 & Yes & No evidence \\
\hline 4 & Khairi Murat & Game Reserve & Attock & 56 & Yes & Yes, c. 50 individuals \\
\hline 5 & Kala Chitta & National Park & Attock & 1,326 & Yes & No evidence \\
\hline 6 & Ayub Park & Other & Rawalpindi & 9 & Yes & No evidence \\
\hline 7 & Ayubia & National Park & $\begin{array}{l}\text { Rawalpindi } \\
\text { (Murree) }\end{array}$ & 17 & No & No \\
\hline 8 & $\begin{array}{l}\text { Murree-Kahuta-Kotli } \\
\text { Sattiyan }\end{array}$ & National Park & $\begin{array}{l}\text { Rawalpindi } \\
\text { (Kahuta) }\end{array}$ & & No & No \\
\hline 9 & Margalla Hills & National Park & Islamabad & 174 & Yes & Yes, c. 7 individuals \\
\hline 10 & $\begin{array}{l}\text { Islamabad Wildlife } \\
\text { Sanctuary }\end{array}$ & $\begin{array}{l}\text { Wildlife } \\
\text { Sanctuary }\end{array}$ & Islamabad & 70 & Yes & No evidence \\
\hline
\end{tabular}

distribution of the Indian pangolin provided by IUCN was retrieved as a shapefile from the Red List of Threatened Species (IUCN, 2014). To examine the occurrence of the Indian pangolin with respect to protected areas, we compared the species' distribution to the locations of the protected areas on the Potohar Plateau, obtained from the World Database on Protected Areas (IUCN, UNEP-WCMC, 2014).

Questionnaire surveys (Supplementary Material 1) were conducted with local people in the study area (including hunters, shepherds, shop keepers and school children) to gather data about illegal capture and killing of Indian pangolins. During the survey period a total of 36 monthly field visits were conducted. Based on information obtained from the questionnaires we recovered a number of dead pangolins (without scales), and scale jackets (which remain after a pangolin has died and decayed). Local people do not use scale jackets for decorative purposes but sell them in local markets.

\section{Results}

\section{Spatial distribution}

We recorded 158 locations across the four Districts of the Potohar Plateau (Attock, 34; Chakwal, 44; Jhelum, 35;
Rawalpindi, 45) where there were direct sightings or indirect signs of Indian pangolins (Fig. 1). Based on these occurrences we determined that the species occurs in c. $89 \%$ $\left(19,854 \mathrm{~km}^{2}\right)$ of the Plateau rather than in the c. $71 \%$ $\left(15,801 \mathrm{~km}^{2}\right)$ indicated in the IUCN Red List account for the species (Baillie et al., 2014; Fig. 1). At least 40 locations (in Rawalpindi and Attock Districts) were outside the range indicated by IUCN. The elevational range of the Indian pangolin on the Plateau was 202-879 m; in Rawalpindi District the species occurred from 457 (Gujar Khan) to 593 m (Kahuta), in Chakwal District from 478 (Mureed) to $879 \mathrm{~m}$ (Basharat Hills), in Jhelum District from 202 (Haranpur Victoria pul) to $631 \mathrm{~m}$ (Sohawa), and in Attock District from 285 (Haddowali) to $523 \mathrm{~m}$ (Durnal).

\section{Illegal capture and killing of the species}

From January 2011 to the end of April 2013 we collected 412 items of evidence of the illegal capture and/or killing of Indian pangolins from 48 locations across all four districts of the Potohar Plateau (Table 1; Fig. 1). The highest number of records of illegal capture or killing were in Chakwal District ( $n=156 ; 13$ locations), followed by Attock ( $n=149$; eight locations), Jhelum ( $\mathrm{n}=57$; eight locations) and Rawalpindi Districts ( $\mathrm{n}=50$; five locations). The highest number of illegal killings occurred in February 
$2013(n=127)$, followed by September $2012(n=92)$, April $2012(\mathrm{n}=57)$ and January $2012(\mathrm{n}=39)$ (Fig. 2).

\section{Protected areas}

The Indian pangolin has been recorded in eight of the 10 protected areas on the Potohar Plateau (Table 2), with no records in Ayubia or Murree-Kahuta-Kotli Sattiyan National Parks. There are reports of poaching and killing of Indian pangolins in some of these eight protected areas (Table 2).

\section{Discussion}

The Indian pangolin was categorized as Near Threatened on the IUCN Red List in 2009 but was recategorized as Endangered in 2014 'because it is subject to hunting and increasing levels of poaching' (Baillie et al., 2014). In Pakistan the species is categorized as Vulnerable (Sheikh \& Molur, 2004). Under the Punjab Wildlife Acts and Rules (1974) it is included in Category Three of the Third Schedule and is therefore protected throughout the year (Shafiq, 2005). Despite being protected, however, the species is heavily hunted for trade (Molur, 2008), although there is limited evidence of the trade or of threats to the species (CITES, 2000). Data on any hunting and trade are required to design effective conservation strategies for the species. Without conservation efforts the population is likely to continue to decline, and could be lost from the wild in Pakistan. Baseline information about the species' biology and ecology, including habitat requirements/preferences, population and feeding habits, is also needed to inform conservation efforts.

We found that the species is widely distributed in all four districts of the Plateau and occupies 18\% more of the Plateau than previously estimated (Baillie et al., 2014). It is possible that the species is broadening its range in response to hunting pressure or, more likely, that it was overlooked previously at some sites because of its cryptic nature. Given the species' low reproductive rate (Roberts, 1997), it could be extirpated from the Plateau without improved protection. Although poachers do not target individuals of a particular sex, 16 of 21 individuals recorded in a separate study were male (T. Mahmood, 2015, unpubl. data). Although this suggests a male-biased sex ratio, the sample size was small, and it is possible that males travel more widely, are more active or are easier to find.

Although pangolins are traded internationally in Asia (Wu \& Ma, 2007; Challender et al., 2015), CITES does not record this trade centrally. Data from seizures of pangolins in Asia (including derivatives, species, and number of individuals in trade) between July 2000 (when zero export quotas for wild-captured individuals of the four Asian pangolin species came into effect) and 2013 indicate the level of trade and provide the most comprehensive means of analysing illicit trade (Rosen \& Smith, 2010; Underwood et al., 2013). Historically, Asian pangolin species have been exploited locally for a range of consumptive uses (e.g. as a protein source, a tonic food, and an ingredient in traditional medicine), most conspicuously in China, but also for the international trade in their scales (Herklots, 1937; Harrisson \& Loh, 1965). The seizure data and records of trade indicate that between July 2000 and December 2013 there were at least 886 seizures involving pangolins in Asia, with an estimated 227,278 individuals traded illegally (Challender et al., 2015). The trade was mainly of scales $(41 \%)$ as well as live and dead individuals $(31 \%)$ and meat (26\%) (Challender et al., 2015).

There are no reports of consumption of pangolin meat in Pakistan, and the limited local trade in pangolin scales does not account for the large number of pangolins killed. Thus we conclude that the high level of poaching is driven by demand for the international trade. At present, the penalty for poaching the Indian pangolin is a fine of c. PKR 10,000 (c. USD 100) and/or 1 week in prison. This is an ineffective deterrent, as a single adult pangolin may be sold for PKR 50,000 (c. USD 500). Recent population estimates indicate the species has declined by c. $79 \%$ (Irshad et al., 2015), and that the decline is ongoing. To reduce poaching of the Indian pangolin and protect the population on the Potohar Plateau we recommend increasing the patrol and enforcement efforts and increasing the penalties for poaching. We passed our findings to the local authorities at District level (Punjab Wildlife and Parks Department, Government of the Punjab) and they have increased their efforts to protect pangolins in the study area. There are now fewer reports of pangolin captures. However, this could also indicate that Indian pangolins are continuing to decline on the Potohar Plateau and poachers are finding fewer individuals.

\section{Acknowledgements}

We thank the Higher Education Commission, Pakistan, for funding provided through Research Project No. 20-1578/ R\&D-09/2436.

\section{Author contributions}

TM designed the study and secured funding for the research. FA, NI and RH collected field data. TM and FA analysed the data and wrote the article. AA, HF and SA assisted with the analysis and writing.

\section{References}

Baillie, J., Challender, D., Kaspal, P., Khatiwada, A., Mohapatra, R. \& Nash, H. (2014) Manis crassicaudata. The 
IUCN Red List of Threatened Species 2014: e.T12761A45221874. Http:// dx.doi.org/10.2305/IUCN.UK.2014-2.RLTS.T12761A45221874.en [accessed 8 February 2017].

Bhut A, I.A. (1999) Achievements and issues in 2oth century in small dams (rainwater harvesting). In Proceedings of the National Workshop on Water Resource Achievements and Issues in 2oth Century and Challenges for Next Millennium, pp. 64-69. Pakistan Council of Research in Water Resources, Islamabad, Pakistan.

Challender, D.W.S., Harrop, S.R. \& MacMillan, D.C. (2015) Understanding markets to conserve trade-threatened species in CITES. Biological Conservation, 187, 249-259.

CITES (2000) Proposal 11.13: Transfer of Manis crassicaudata, M. pentadactyla, M. javanica from Appendix II to Appendix I. Https://www.cites.org/eng/cop/11/prop/13.pdf [accessed 20 March 2017].

CITES (2017) The CITES Appendices. Http://www.cites.org/eng/app/ index.shtml [accessed 8 February 2017].

Eia (Environmental Investigation Agency) (2015) Illegal trade seizures: pangolins. Https:/eia-international.org/ illegal-trade-seizures-pangolins [accessed 8 February 2017].

Encyclopaedia Britannica (2010) Potwar Plateau. Http://www. britannica.com/EBchecked/topic/472944/Potwar-Plateau [accessed 8 March 2017].

GaCC (General Administration of Customs, People’s Republic of China) (2012) Http://www.customs.gov.cn/publish/ portalo/tab39267/info365276.htm [accessed 20 March 2017]. [In Chinese]

Gaubert, P. (2011) Family Manidae (Pangolins). In Handbook of the Mammals of the World. Volume 2 (eds D.E. Wilson \& R.A. Mittermeier), p. 886. Lynx Edicions, Barcelona, Spain.

Gaudin, T.J., Emry, R.J. \& Pogue, B. (2006) A new genus and species of pangolin (Mammalia, Pholidota) from the late Eocene of Inner Mongolia, China. Journal of Vertebrate Paleontology, 26, 146-159.

Harrisson, T. \& Loh, C.Y. (1965) To scale a pangolin. The Sarawak Museum Journal, 12, 415-418.

Herklots, G.A.C. (1937) The pangolin or scaly ant-eater. The Hong Kong Naturalist, 8, 2, 78-83.

Irshad, N., Mahmood, T., Hussain, R. \& Nadeem, M.S. (2015) Distribution, abundance and diet of the Indian pangolin (Manis crassicaudata). Animal Biology, 65, 57-71.

IUCN (2014) The IUCN Red List of Threatened Species v. 2014.3. Red List Spatial Data. Http://www.iucnredlist.org/technical-documents/ spatial-data [accessed 20 November 2014].

IUCN, UNEP-WCMC (2014) The World Database on Protected Areas. UNEP World Conservation Monitoring Centre, Cambridge, UK. Http://www.protectedplanet.net [accessed 5 March 2013].

LIM, N.T.L. \& NG, P.K.L. (2008) Home range, activity cycle and natal den usage of a female Sunda pangolin Manis javanica (Mammalia: Pholidota) in Singapore. Endangered Species Research, $4,233-240$.
Mahmood, T., Hussain, R., Irshad, N., Akrim, F. \& Nadeem, M.S. (2012) Illegal mass killing of Indian pangolin (Manis crassicaudata) in Potohar region, Pakistan. Pakistan Journal of Zoology, 44, 1457-1461.

Molur, S. (2008) Manis crassicaudata. In The IUCN Red List of Threatened Species v. 2012.1. Http://www.iucnredlist.org [accessed 27 August 2012].

PAI, M. (2008) The Indian porcupine. Http://mohanpaisarticles. blogspot.co.uk/2008/10/vanishing-species-indian-porcupine.html [accessed 20 March 2017].

QGiS Development Team (2012) QGIS Geographic Information System. Open Source Geospatial Foundation Project. Http://www. qgis.org/.

Roberts, T.J. (1997) Mammals of Pakistan. Oxford University Press, Karachi, Pakistan.

Rosen, G.E. \& S Mith, K.F. (2010) Summarizing the evidence on the international trade in illegal wildlife. EcoHealth, 7, 24-32.

ShafiQ, M.M. (ed.) (2005) Wildlife Acts and Rules of Pakistan. Forestry Sector Research and Development Project, Pakistan Forest Institute, Peshawar, Pakistan.

SheiKh, K.M. \& Molur, S. (eds) (2004) Status and Red List of Pakistan's Mammals. Based on the Conservation Assessment and Management Plan. IUCN Pakistan, Karachi, Pakistan.

Underwood, F.M., Burn, R.W. \& Milliken, T. (2013) Dissecting the illegal ivory trade: an analysis of ivory seizures data. PLOS ONE, 8 (10), e76539.

WebGIS (2012) Terrain data. Http://www.webgis.com/terr_world.html [accessed 20 March 2017].

Wu, S.B. \& MA, G.Z. (2007) The status and conservation of pangolins in China. TRAFFIC East Asia Newsletter, 4, 1-5.

Yang, C.W., Chen, S., Chang, C.Y., Lin, M.F., Block, E., Lorentsen, R. \& Dierenfeld, E.S. (2007) History and dietary husbandry of pangolins in captivity. Zoo Biology, 26, 232-230.

\section{Biographical sketches}

TARIQ MAHMOOD's research interests include the ecology of mammals, animal physiology, geographical information systems, and toxicology. FARAZ A KRIM studies the ecology of the Indian pangolin on the Potohar Plateau. NA USHEEN IRSHAD is interested in wildlife management and has conducted research on the distribution, population and food habits of the Indian pangolin on the Potohar Plateau. RIAZ HUSSAIN conducts research on the ecology of small mammals. Hir A Fatima's interests include the ecology of mammals. Shaista ANDLEEB is interested in the ecology of small mammals, and has conducted field research on the habitat, distribution and population estimation of the Indian pangolin in Margallah Hills National Park, Islamabad. Ayesha Ainetasham's interests include biodiversity and entomology. 